\title{
What does an inventory of recent innovation experiences tell us about agricultural innovation in Africa?
}

\author{
Bernard Triomphe ${ }^{1}$, Anne Floquet ${ }^{2}$ Geoffrey Kamau ${ }^{3}$, Brigid Letty ${ }^{4}$, Simplice Davo Vodouhe ${ }^{2}$, \\ Teresiah N'gan'ga ${ }^{2}$, Henri Hocdé \\ 1 CIRAD UMR Innovation, 34398 Montpellier cedex 5, France \\ 3 KARI Headquarters, Kaptagat Rd, Loresho Nairobi, Kenya \\ 2 Faculté des Sciences agronomiques, Université d'Abomey-Calavi, 01 BP 526 Cotonou, Bénin \\ 4 Institute of Natural Resources, PO Box 100 396, Scottsville, 3209, South Africa \\ 5 CIRAD UMR ART-DEV, 34398 Montpellier cedex 5, France
}

Keywords: Inventory, innovation processes, analytical framework, multiple stakeholders, agriculture, small holders, Benin, Kenya, South Africa

\begin{abstract}
Within the context of the FP7 JOLISAA project (JOint Learning in and about Innovation Systems in African Agriculture), an inventory of agricultural innovation experiences was developed in three African countries: Kenya, South Africa and Benin. The main objective was to assess a broad diversity of multi-stakeholder agricultural innovation processes involving smallholders. National teams used literature searches and interactions with a range of institutions and networks engaged in agricultural innovation to identify cases. Interviews with resource persons and field visits were also conducted to supplement the available / accessible documentation. The inventory was made according to a common analytical framework and guidelines inspired by the Innovation System perspective to allow for an analysis across cases and countries.

The completed inventory includes 57 documented cases, covering a wide diversity of experiences, in terms of types, domains, scales and timelines of innovation. The 57 cases confirm previously documented features, such as the diversity of stakeholders involved in innovation, the diversity of innovation triggers, or also the frequent occurence of market driven innovation. It also illustrates more original features: the typically long time frames of innovation processes; the common occurrence of "innovation bundles" (a combination over time of technological, social and/or institutional innovations); and an often close relationship between innovation and externally-funded projects.

National teams faced several challenges during the inventory process, including a common understanding and consistent use of key innovation-related concepts, and a difficult access to relevant information related partly to restrictions put by several case holders on sharing openly their experience.

Out of the inventory, JOLISAA has selected thirteen cases which will undergo a subsequent phase of collaborative assessment. The assessment will strive to assess issues the inventory could not tackle, such as the actual roles and contributions of the various stakeholders, the dynamics of the innovation process, and the influence of the enabling environment on the innovation process and outcome.
\end{abstract}




\section{Introduction}

Today, many institutions at the national and international level pay increasing attention to innovation and how it can best be nurtured (Hall et al., 2003; World Bank, 2006, Röling, 2009). A dynamic innovation landscape is considered essential to provide some of the answers required to adapt to a fast-changing world in which climate change, increasing urbanization, globalization or concerns with the preservation of the environment all contribute to re-assessing the values, performance and current practices of economic actors. This trend also affects the agricultural and rural development sector, and especially developing countries where many people still depend on agriculture for their livelihoods.

Yet an accurate and fact-based understanding of innovation systems and processes in agriculture remains limited (Rajalahti et al., 2008). Despite the increased use of participatory approaches, most researchers and practitioners still tend to consider innovation as a mostly linear process. In this model, research produces new knowledge and develops inventions, based mostly on its own diagnosis of the problems and needs of its "clients" (mostly farmers and other rural stakeholders in our case). It then passes these potential solutions over to an extension or diffusion system of some sort, which in turns tries to convince farmers to apply them in order to achieve adoption and impact. Despite its success under specific conditions, this model does not take into account how innovation usually happens. Proponents of innovation systems (IS) (Hall et al., 2003, World Bank, 2006; Spielman et al, 2009,) and actor-network theory (Latour, 2005) have shown that innovation rather takes place within heterogeneous networks, in which diverse stakeholders such as researchers, farmers and their organizations, private entrepreneurs, NGOs, government and other stakeholders interact in a non-linear, iterative and non-predictable fashion to solve a common problem, adapt to a new environment or take advantage of new opportunities. The outcome of such interactions usually consists of a mix of technical, organizational and institutional innovations developed and refined on the go.

JOLISAA (Joint-Learning in and about Innovation Systems in African Agriculture) is an EU-funded project under the FP7 scheme. Its four EU-based and three Africa-based consortium members aim to assess jointly recent or on-going innovation experiences in Benin, Kenya and South Africa, as a basis for identifying relevant lessons and recommendations in terms of policy, research and practice. In 2010, JOLISAA launched an inventory of innovation experiences. The aim was to take stock of the diversity of multi-stakeholder agricultural innovation experiences involving smallholders and to assess them broadly according to a common framework.

This paper provides insights about the initial inventory results. It also draws a series of lessons and challenges regarding key features of the innovation experiences themselves and the way the inventory was conducted.

Materials and methods: the inventory of innovation experiences

The inventory was implemented in 3 countries: Benin, Kenya and South Africa and focused on agricultural innovation experiences. Three main inclusion criteria were used for searching for cases to be considered for the inventory: (1) small holder and other resource-poor rural stakeholders actively involved; (2) at least three different types of stakeholders actively involved, (2) experiences at least 3 years old and over the initial stages of innovation. JOLISAA did take on board cases related to any type and domain of innovation (agricultural production, processing, marketing, natural resource management, etc.) and to any scale at which innovation took place (from local to national).

Two different routes were followed to search for experiences. The first route was institutional, by targeting resource persons linked to specific institutions (universities, research institutes and networks which were part of the national agricultural innovation landscape), or to specific innovation 
cases known before-hand by JOLISAA national teams. The second route was geographical, by focusing on a given region, area or farming systems within each country.

A common analytical framework was developed to characterize broadly the inventory cases. It drew on the innovation system concept and perspective (Hall, 2003; World Bank, 2006) and on the actornetwork theory (Latour, 2005). It focused on innovation types, nature and domain, on stakeholders, their roles and interactions, on innovation triggers and drivers, on innovation dynamics and scale, and on results obtained (Table 1).

Operationally, the framework was declined in two complementary templates (Table 1). A spreadsheet template consisted of a series of semi-quantitative variables for describing major dimensions of each innovation case. A text template allowed for the development of concise freeflowing narratives about key qualitative aspects of the innovation experiences.

Table 1 Main categories and variables used for the Inventory templates.

\begin{tabular}{|c|c|c|c|}
\hline $\begin{array}{l}\text { Theme / Dimension } \\
\text { / variable }\end{array}$ & $\begin{array}{c}\text { What JOLISAA } \\
\text { wanted to know about it }\end{array}$ & $\begin{array}{l}\text { Included in } \\
\text { spreadsheet? }\end{array}$ & $\begin{array}{c}\text { Included in } \\
\text { text narrative? }\end{array}$ \\
\hline $\begin{array}{l}\text { Innovation: type, } \\
\text { nature, domain }\end{array}$ & $\begin{array}{l}\text { What was the diversity of innovations } \\
\text { addressed? }\end{array}$ & Yes & Description \\
\hline $\begin{array}{l}\text { Stakeholders' roles } \\
\text { \& interactions }\end{array}$ & $\begin{array}{l}\text { Who have been leading or active } \\
\text { stakeholders? What type of coordination } \\
\text { has taken place among stakeholders? }\end{array}$ & Basics & $\begin{array}{l}\text { Table and } \\
\text { description }\end{array}$ \\
\hline $\begin{array}{ll}\text { Role of local } \\
\text { knowledge }\end{array}$ & Has local knowledge played a role? & No & Basics \\
\hline $\begin{array}{l}\text { Innovation triggers } \\
\text { \& drivers }\end{array}$ & $\begin{array}{l}\text { What have been the key triggers and } \\
\text { drivers of the innovation process? }\end{array}$ & $\begin{array}{c}\text { key categories } \\
\text { only }\end{array}$ & in some details \\
\hline $\begin{array}{l}\text { Innovation } \\
\text { dynamics }\end{array}$ & $\begin{array}{l}\text { What have been the key phases the } \\
\text { innovation process went through from } t_{0} \\
\text { 'til the present day }\end{array}$ & No & $\begin{array}{l}\text { Main phases } \\
\text { from } t_{0} \text { to today }\end{array}$ \\
\hline $\begin{array}{l}\text { Scale at which } \\
\text { innovation is taking } \\
\text { place }\end{array}$ & $\begin{array}{l}\text { Whether the innovation process took } \\
\text { place mainly at local, regional, national } \\
\text { scale, or at several scales? }\end{array}$ & Basics & In some details \\
\hline $\begin{array}{l}\text { Results and } \\
\text { "Impact" obtained }\end{array}$ & $\begin{array}{l}\text { What have been the effects so far, } \\
\text { positive or negative, intended or not, in } \\
\text { different dimensions? }\end{array}$ & Basis & $\begin{array}{c}\text { List of results I } \\
\text { effects of } \\
\text { different kinds }\end{array}$ \\
\hline
\end{tabular}

\section{Main results of the inventory}

\section{Key characteristics of the national inventories}

More than a hundred potential cases were initially identified (Table 2), but about half of them did not meet the JOLISAA inclusion criteria. Either there were too few stakeholders, or the experiences were still incipient, or it was impossible to actually pinpoint the actual innovation angle within what amounted to development-oriented rather than innovation initiatives, or resource persons were not accessible. The inventory eventually documented 57 cases (Table 2 ). The variability in the number of documented cases in each country reflected a number of interlinked factors: the initial familiarity of each national team with innovation cases and resource persons, the relative ease with which they were able to link up with appropriate resource persons, networks and institutions, the actual routes followed for case identification, the willingness of case holders to share information about their experiences. Who actually documented the cases also played a pivotal role: Benin and Kenya documented more cases as they were able to mobilize resource persons external to the national teams. Benin opted to rely on closely supervised young graduates to sift through existing 
documentation, interview resource persons and conduct some field visits. Kenya opted to rely on KARI site researchers based in five regional research centers across the country. South Africa for its part opted to contact resource-persons with an electronic questionnaire followed by telephonic interviews.

Whatever differences in approaches and number of cases were, a broad diversity of cases was as expected unearthed in each country (Tables 2 and 3). Cases documented touched on many different domains of innovations, related to agricultural or animal (including fish) production, but also to natural resource management, produce processing and marketing. Innovation experiences developed at scales ranging from local to national. Diverse stakeholders, including farmers, NGOs, research or private sector played an active role, even though truly farmer-led cases were few, probably because they were less visible and also less frequently documented.

Table 2: Key characteristics of the national inventories of innovation experiences implemented by JOLISAA national teams in Benin, Kenya and South Africa

\begin{tabular}{|c|c|c|c|}
\hline $\begin{array}{l}\text { Key characteristics of } \\
\text { the inventory }\end{array}$ & Benin & Kenya & South Africa \\
\hline $\begin{array}{l}\text { Number of Cases in the } \\
\text { inventory (identified } \rightarrow \\
\text { documented) }\end{array}$ & $>40 \rightarrow 28$ & $28 \rightarrow 18$ & $39 \rightarrow 11$ \\
\hline $\begin{array}{l}\text { Approach used for } \\
\text { documenting cases }\end{array}$ & $\begin{array}{l}\text { Lit. review + } \\
\text { Interviews + } \\
\text { field visits }\end{array}$ & $\begin{array}{l}\text { Interviews + } \\
\text { Field visits + } \\
\text { Lit. review }\end{array}$ & $\begin{array}{l}\text { E-mail questionnaire } \\
+ \text { interviews }\end{array}$ \\
\hline $\begin{array}{l}\text { Who documented the } \\
\text { cases? }\end{array}$ & $\begin{array}{l}\text { Young graduates } \\
+ \text { national team }\end{array}$ & $\begin{array}{l}\text { KARI on-site } \\
\text { researchers } \\
+ \text { national team }\end{array}$ & $\begin{array}{l}\text { national team } \\
\text { + case-specific } \\
\text { resource persons }\end{array}$ \\
\hline $\begin{array}{l}\text { Main Domains of } \\
\text { innovation }\end{array}$ & $\begin{array}{l}\text { Agriculture, fisheries, } \\
\text { processing, access } \\
\text { to markets }\end{array}$ & $\begin{array}{l}\text { Agriculture, live- } \\
\text { stock, processing, } \\
\text { access to markets }\end{array}$ & $\begin{array}{l}\text { Agriculture, } \\
\text { processing \& } \\
\text { marketing }\end{array}$ \\
\hline Main types of innovation & \multicolumn{3}{|c|}{$\begin{array}{l}\text { Technical, organizational and institutional, } \\
\text { usually linked ("bundled") one with another }\end{array}$} \\
\hline $\begin{array}{l}\text { Main / lead stakeholders } \\
\text { (in decreasing order of } \\
\text { frequency) }\end{array}$ & $\begin{array}{l}\text { 1. Research / R\&D } \\
\text { projects } \\
\text { 2. Farmers, CBOs \& } \\
\text { FOs; } \\
\text { 3. Private Entrepren. }\end{array}$ & $\begin{array}{ll}1 . & \text { Research } \\
2 . & \text { R\&D projects } \\
\text { 3. } & \text { Extension } \\
\text { Farmers }\end{array}$ & $\begin{array}{ll}\text { 1. Farmers, Research, } \\
\text { 2. NGOs } \\
\text { 3. Extension }\end{array}$ \\
\hline $\begin{array}{l}\text { Time line of innovation } \\
\text { cases }\end{array}$ & $\begin{array}{l}\text { Several decades } \\
\text { to a few years }\end{array}$ & $\begin{array}{c}\text { A few years } \\
\text { to a decade or more }\end{array}$ & $\begin{array}{l}\text { Typically } \\
\text { a few years }\end{array}$ \\
\hline $\begin{array}{l}\text { Main scales at which } \\
\text { innovation is taking } \\
\text { place }\end{array}$ & $\begin{array}{l}\text { Local, regional, } \\
\text { national, } \\
\text { international }\end{array}$ & $\begin{array}{l}\text { Local, regional, } \\
\text { national }\end{array}$ & Mostly local \\
\hline
\end{tabular}


Table 3: Diversity of innovation experiences in the inventories of Benin, Kenya and South Africa

\begin{tabular}{|l|c|c|c|}
\hline Theme of inventory cases & Benin & Kenya & S. Africa \\
\hline Restoring \& managing soil fertility & $\mathrm{X}$ & $\mathrm{X}$ & $\mathrm{X}$ \\
\hline $\begin{array}{l}\text { Increasing moisture capture and managing water to boost } \\
\text { crop productivity }\end{array}$ & $\mathrm{X}$ & $\mathrm{X}$ & \\
\hline Participatory breeding & $\mathrm{X}$ & & \\
\hline New post-harvest conservation or processing techniques & $\mathrm{X}$ & \\
\hline $\begin{array}{l}\text { Protecting natural resources (water, wild species, forest) by } \\
\text { developing new ways of producing and new sources of } \\
\text { incomes }\end{array}$ & $\mathrm{X}$ & $\mathrm{X}$ & \\
\hline $\begin{array}{l}\text { Multi-stakeholder platforms \& committees for managing } \\
\text { natural resources (fisheries, irrigation water, etc.) }\end{array}$ & $\mathrm{X}$ & $\mathrm{X}$ & $\mathrm{X}$ \\
\hline $\begin{array}{l}\text { Contract farming (certified seed production, linking farmers } \\
\text { to agro-industry }\end{array}$ & $\mathrm{X}$ & $\mathrm{X}$ \\
\hline $\begin{array}{l}\text { New value chains (organic cotton / cotton made in Africa / } \\
\text { organic pineapple/ dried mangos, soybean production, } \\
\text { ginger drink, etc.) }\end{array}$ & $\mathrm{X}$ & \\
\hline
\end{tabular}

An initial cross-analysis of the inventory cases

A simple comparison of inventorys cases based on their main features was carried out.

A number of trends detected confirm observations made elsewhere. For one, the emergence of market-driven innovation has been reported in many recent surveys of innovation in Africa (e.g. Adekunle et al., 2012) and is duly reflected in many inventory cases across the 3 countries. Market innovation takes place through different channels: emergence of new value-chain arrangements, the taking into account by producers of a consumer or industry demand or standard. There is also the more traditional yet still critical issue of access to inputs. Most of the market-related cases combine elements of technical innovation with organizational or institutional ones. While linking to the markets is increasingly considered vital for improving smallholders' livelihoods, accessing markets for products, inputs or capital is not straightforward for them, as it implies tangible risks and requires collective action, which itself usually requires significant support from other stakeholders. Remarking on the diversity of stakeholders involved in innovation has become fairly common place, especially in the wake of IS approaches (e.g. Hounkounou et al., 2012). The typical stakeholder list for a given inventory case includes a mix of individual farmers-innovators, one or several community-based or farmer organizations, formal research, extension services, NGOs, private entrepreneurs, government, etc. Externally-funded R\&D projects also appear as major stakeholders in many inventory cases (see below). Depending on the specific case and also on the phase of innovation, lead and active stakeholders vary. For instance, research, an NGO or a R\&D project might be very active in initial stages (conducting diagnosis and on-farm experimentation, providing capacity-building, etc.), while farmers and their organizations, or a business stakeholder become more active in subsequent phases. Interestingly, while usually present and active, research does not necessarily appear to play a leading role or to be the initiator of innovation in many inventory cases, as ideas and initiatives come from different sources, including the farmers themselves. Conversely, decision and policy-makers, and to a lesser extent private sector organizations hardly appeared among the active stakeholders of JOLISAA inventory cases. This might reflects the relative scarcity of specific pro-innovation public policies in the countries under study, as well as a relative weakness of the inventory framework about such dimensions. It also reflects the limited connections of national teams with what still remains for them non-conventional partners. The inventory also shows that there are many different ways of organizing the interactions among stakeholders: in some cases, interactions remain rather 
informal, while in others, they take place under the umbrella of a R\&D project. They can also take the form of a multi-stakeholder platform, especially when a common resource (e.g. a mangrove, an irrigation scheme, a forest) needs to be managed (Hounkounou et al., 2012) or when such a platform is organized under the umbrella of a project. In many inventory cases, one of the stakeholders (typically a research institute, an NGO), usually plays the role of intermediary (Klerkx and Leeuwis, 2008) to facilitate interactions among stakeholders.

Innovation triggers were fairly diverse among inventory cases, and most cases present a mix of triggers of various kinds. Degradation of natural resources (e.g. declining soil fertility, or a dwindling supply of water, a disappearing forest), is among the most common triggers mentioned. Other triggers include seizing a local or global market opportunity, or frequently, introducing a new, improved technology or practice (such as an improved breed of livestock, a new way of parboiling rice, a fertility-improving input). Changes in policy were however rarely mentioned.

Other trends emerging from the cross-analysis are perhaps more original. For many inventory cases, the relevant innovation time frame for understanding the innovation process can easily span more than 10 years, sometimes even several decades (as several inventory cases in Benin and Kenya illustrate). There is obviously an element of choice in deciding what constitutes a legitimate starting point for characterizing a given innovation process. But more importantly, JOLISAA teams wanted to reflect the fact that innovation processes often seem to go through several consecutive phases (World Bank, 2006). This in turn reflects the rather uneven pace of innovation processes over time and space, sometimes very brisk, sometimes rather dormant, under the influence of varying and constantly changing triggers and drivers related to the overall enabling environment. In Kenya for instance, the initial introduction of the Prosopis sp. as a way to restore degraded lands was considered a success until it was perceived by farmers as an obnoxious invasive species which had to be eradicated. Faced with this challenge, a new innovation iteration took place which eventually yielded viable strategies and options for managing and using Prosopis by using its pods for forage, by burning it to produce high-quality charcoal, and by producing quality honey from Prosopis stands. The seemingly frequent occurrence of such a changing innovation landscape over time questions the ability and relevance of the many existing assessments based on shorter time-lines to reflect, not to mention predict, the actual fate of what should perhaps be called initial innovations, to differentiate them from final innovations.

As the IS concept itself predicts, many concrete innovations resulting from a given innovation process exhibited several interwoven dimensions: technical (e.g., a new variety, a new technology), but also organizational (farmers acting collectively to acquire inputs or sell their produce) or institutional (new coordination mechanisms, new companies). These various dimensions did not usually materialize from the start: building on a specific entry point (usually around a new technology), other dimensions emerged on the go as the innovation process unfolded. This was especially true when considering a long time line. JOLISAA internally refers to this situation as "innovation bundles". New dimensions may result from new stakeholders coming on-board, or simply from stakeholders starting to actually change their practices and in so doing, transforming or taking advantage in different ways of the environment in which they operate. The evolution of soybean growing and processing in Benin offers a striking example of such a bundle. Soybean was first introduced in the 1970 s as an infant protein-rich food while farmers were shown how to grow it and use it in traditional cooking recipes. After a long latency period, soybean growing increased in central Benin as the cotton value-chain underwent a multi-pronged prolonged crisis. This prompted oil processing factories to develop contractual arrangements with farmers and their organizations to replace cotton seed with soybean. In recent years, as an alternative to the powerful industrial soybean oil value chain, farmers' organizations have supported producer-led soybean food chains based on small scale soybean cheese and oil processing equipment, coupled with the development of poultry husbandry using the soybean bran. 
Unsurprisingly perhaps, many inventory cases document the visible and well-known innovations entertaining a strong link with externally-funded projects. The abundance of "projects" in charge of spurring innovation is indeed typical of developing countries: as national public funding for innovation is scarce, public institutions and NGOS depend on external support to implement innovation-related activities, while smallholders are usually too poor to pursue innovation at a significant / formal scale on their own. Yet the relationship between innovation and projects seems ambivalent at best. On the one hand, projects are very important for creating an innovation dynamics embedded in a temporary favorable (and artificial) enabling environment, shielding the process from usual inhibiting factors. They are able to do so because of the leverage they exert on human and financial resources, the opportunities they create for linking stakeholders one to another and the intensity of innovation-related activities they activate and support. This allows to reach a minimum critical mass or threshold and to overcome initial bottlenecks for innovation. On the other hand, projects often artificially trigger and support activities and short-term uses of technologies and other innovations which may not be sustainable, at times not even desirable, on their own. Moreover, projects frequently trigger opportunistic behaviors from a variety of stakeholdersand tend to induce a culture of assistance. At the same time, projects tend to overlook more endogenous, local, low-cost and potentially more sustainable innovation pathways and outcomes. Analyzing the conditions under which projects could indeed give way to sustainable innovation and development dynamics is however beyond the scope of the JOLISAA inventory.

Key challenges met in developing the inventory, and ways around them Documenting innovation processes may appear to be a relatively straightforward and quick task. Yet it constitutes a fairly new and challenging endeavor for the few researchers and professionals willing to embark on such a task. Beyond the more obvious logistical challenges, never to be underestimated in the context of poorly-endowed institutions, JOLISAA identified two types of challenges which require careful attention.

For one, developing a common understanding and uniform use of innovation-related concepts is rather difficult, a challenge others have already reported (Spielman et al., 2009; Pyburn and Hills, 2011). Concepts such as innovation processes and systems, stakeholders and their contributions, the enabling environment are all fairly complex and fuzzy, and the different disciplines and professionals who interacted for the purpose of the JOLISAA inventory understood and used them in very loose, at times conflicting ways. Unfortunately, JOLISAA lacked the time and resources to invest enough in up-front and iterative face-to-face discussions and formal crosscountry capacity-building. Electronic exchanges and sharing of documents among a set of heterogeneous partners soon reaches stringent limits when it comes to building a common culture and implementing a common approach. As a result, many documenters of inventory cases did not fully grasp the meaning and implications of the inventory framework. Hence they struggled to reconstitute and qualify properly inherently dynamic and complex innovation processes. They tended instead to simply list stakeholders involved and describe tangible, visible innovation activities (such as experimentation, workshops, etc.) and outcomes (and especially technologies), a more modest achievement than was initially expected. How to properly overcome these conceptual weaknesses and barriers constitutes a challenge.

Accessibility of relevant information and of informants was also a recurrent challenge, a difficulty JOLISAA had not quite anticipated. Yet it seems rather ubiquitous across Africa despite the advent of Internet-based electronic resources. Some cases were not at all documented to start with, because either they were conducted outside a formal project setting (or extended beyond the project life time), or because research, typically in charge of documentation, had not been involved in the innovation process. When documentation existed, e.g. in adoption studies, it contained usually precious little information about the innovation process, a definite blind angle in the 
literature until now. In some instances, intellectual property rights (IPR) issues prevented documentation to proceed for a number of reasons. Allied to an expectation that JOLISAA would somehow pay for getting access to the information it needed, this decreased the number of cases actually documented, especially in South Africa. This general tendency towards restricted and paid access to information goes counter to the somewhat naïve belief held by JOLISAA (and other similar initiatives) in free and extensive sharing of information as a basis for identifying lessons. Offering such vague future rewards as sharing of results, joint learning, or lobbying for favorable policies seems too meager an incentive for many individuals and organizations to want to take part in an inventory, whatever noble goals it purports to achieve. However, as compiling and assessing systematically fairly large sets of experiences is deemed increasingly strategic (e.g. ODI, 2012.), then more realistic modalities and incentives for sharing should be put in place, including clear IPR guidelines.

Discussion: what is the value of the JOLISAA inventory?

Considering the significant efforts and resources invested in the inventory and the results it yielded so far, a relevant question to ask is whether this was worth the effort. Clearly, our answer to this question does not limit itself to considering the purely scientific value of the inventory, as JOLISAA aims to deliver lessons for policy and practice as well as for research.

Arguably, some of the lessons that the inventory has unearthed so far are not very new and have indeed already been highlighted in other studies and foras: see for example Sanginga et al. (2009) about the value of local innovation, Horton and al. (2009), Faure et al. (2010) and Hounkonou et al. (2012) about the value and challenges of multi-stakeholder partnerships and platforms, Adekunle et al. (2012) about the role of facilitation and brokering. Yet other lessons might be more original, such as the need for, and interest of adopting longer time lines to fully comprehend innovation dynamics. Another key lesson relates to the ambiguous yet strategic link between innovations and externallyfunded projects, an ever relevant issue for many developing countries.

Based on such results, national JOLISAA teams consider their participation in the inventory has enhanced their ability to think about and look at innovation processes. It has also helped them come up with a broader understanding of the diversity of innovation processes and associated stakeholders in their respective countries. Some of them already started to use the inventory results to engage in a constructive dialogue with national policy- and decision-makers about the conditions required for supporting innovation. Such dialogue will complement and built on recent global initiatives such as the Agricultural Innovation Sourcebook (World Bank, 2012).

More globally, the JOLISAA inventory, among other similar efforts (e.g. Adekunle et al., 2012) contributes to illustrate that African agriculture is alive and vibrant, and responding actively to the many challenges it faces with respect to eradicating poverty, increasing food security, and managing natural resources in a sustainable way, among others. This may contribute to counter some of the deep-seated pessimism and periodic negative publicity African agriculture frequently attracts. The inventory may also have a strong motivational value: other institutions across Africa may want to emulate JOLISAA by documenting many more and why not "better" innovation cases on their own. This would undoubtedly be useful and greatly expand the fragmented existing knowledge about what is going on in African agriculture. It would further contribute to changing perceptions and increasing the motivation of many for making innovation happen across Africa. Without waiting for new cases to pour in, the JOLISAA inventory, complemented possibly by other studies already documented using an IS framework, offers many possibilities for drawing crosscomparisons and lessons within and among countries. While this paper constitutes a first attempt at it, subsequent inquiries can and will be conducted within and outside the JOLISAA framework. For example, specific types of innovation can be compared one to another across countries. The mix of 
stakeholders and the specific roles they played, or the dynamics of innovation processes taking place in contrasting environments.can also be assessed in a comparative manner, among others.

\section{Conclusions and perspectives}

The inventory developed within the framework of the JOLISAA project shows that many diverse, on-going multi-stakeholder innovation initiatives have taken place in recent years or are still ongoing in the three target countries in Africa. These experiences illustrate that smallholders, far from only producing for subsistence, actively try to link up with markets to buy inputs, sell and transform their produce and thus obtain added value. New technologies are still very important in shaping innovation, but organizational and in some case institutional innovations are also very present, usually in tight relationships with technological ones.

By engaging actively with other stakeholders whose spectrum goes well beyond the traditional extension and research spheres, farmers are challenged to acquire new capacities and skills and receive much-needed support to pursue innovation. Many of the stakeholders which whom they collaborate seem increasingly aware of the need for, and benefit from collaboration with farmers and their organizations, as well as with each other. This allows them to tackle complex problems and challenges that they could not possibly handle on their own, and this contributes to achieve overall development goals at the local and national scales.

Beyond the inventory, JOLISAA will now pursue its work by assessing 13 of the 57 inventory cases in some details in a collaborative manner. Key issues to be assessed in detail include the actual roles and contributions of the various stakeholders, with a specific focus on smallholders' contributions, the dynamics over time of innovation processes in relation to the enabling environments and to the triggers and drivers of innovation, among others. In doing so, it will contribute to a more thorough understanding of innovation processes and systems and to the development of a field-tested, realistic analytical framework for assessing them in a participatory manner.

\section{Acknowledgement}

This work was carried out as part of the EU funded project Joint learning in and about Innovation Systems in African Agriculture (JOLISAA, www.jolisaa.net). The opinions expressed herein are the sole responsibility of the authors. The authors wish to thank the JOLISAA consortium members and its partners in Benin, Kenya, and South Africa for helpful comments, provision of data and additional assistance.

References

Adekunle AA, Ellis-Jones J, Ajibefun I, Nyikal RA, Bangali S, Fatunbi O and Ange A, (2012). Agricultural innovation in sub-Saharan Africa: experiences from multiple-stakeholder approaches. Forum for Agricultural Research in Africa (FARA), Accra, Ghana.

Faure, G. Gasselin, P., Triomphe, B., Temple, L., Hocdé, H. (2010). Innover avec les acteurs du monde rural. La recherche-action en partenariat. Collection «Agricultures tropicales en poche ». QUAE, CTA, Presses Agronomiques de Gembloux, 222 .

Hall, A., VR. Sulaiman, N. Clark, B. Yogoband (2003). From measuring impact to learning institutional lessons: an innovation systems perspective on improving the management of international agricultural research. Agricultural Systems 78: 213-241

Horton, D, Prain, G. and Thiele, G. (2009). Perspectives on partnership: A literature review. International Potato Center (CIP), Lima, Peru. Working Paper 2009-3. 111 p.

Hounkonnou D., Kossou D., Kuyper T.W., Leeuwis, C., Nederlof S., Röling N., Sakyi-Dawson O., Traoré M., van Huis A. (2012). An innovation systems approach to institutional change: 
Smallholder development in West Africa. Agricultural Systems 108 (2012) 74-83

Klerkx L, Leeuwis C(2008). Matching demand and supply in the agricultural knowledge infrastructure: experiences with innovation intermediaries. Food Policy 33: 260-76.

Latour, B. (2005). Reassembling the Social: An Introduction to Actor-Network Theory. Oxford University Press, Oxford, $301 \mathrm{p}$.

ODI(2012). Making systematic reviews work for international development research. Briefing Paper 1, Secure Livelihoods Research Consortium, London, January 2012, 4 p.

Pyburn, R., Woodhill, J. (eds.)(2011). Dynamics of Rural Innovation: A primer for emerging professionals. KIT Publishers, Amsterdam, $128 \mathrm{p}$.

Rajalahti R., Janssen W., Pehu E.(2008). Agricultural Innovation Systems: from diagnostics toward operational practices, Discussion Paper 38, Washington, World Bank, 105 p.

Röling N. (2009). Conceptual and methodological developments in innovation. In Innovation Africa: enriching farmers' livelihoods. Sanginga P, Waters-Bayer A, Kaaria S, Njuki J, Wettasinha C (eds). London, Earthscan.

Sanginga P, Waters-Bayer A, Kaaria S, Njuki J, Wettasinha C (eds), (2009). Innovation Africa: enriching farmers' livelihoods. London, Earthscan

Spielman D., Ekboir J., Davis K. (2009). The art and science of innovation systems inquiry: Applications to Sub-Saharan African agriculture. Technology in Society, 13: 399-405

World Bank, (2006). Enhancing Agricultural Innovation: How to Go Beyond the Strengthening of Research Systems, Washington, World Bank

World Bank, (2012). Agricultural Innovation Systems. An Investment Sourcebook, Washington, World Bank, $658 \mathrm{p}$. 